\title{
Analiza doświadczeń związanych z wykorzystaniem głosowania internetowego (i-voting) w wybranych państwach ${ }^{1}$
}

Analysis of experiences related to the use of voting over the Internet (i-voting). Selected examples: In contemporary states there appear more and more opinions on crisis of democracy and lowering of turnout in general elections. So, many experts state that in times of dynamic development of ICT tools traditional ways of voting should be supplemented by alternative methods of voting, including electronic voting. The aim of this article is to analyze experiences related to the implementation and use of internet voting (as a form of electronic voting) in selected countries. The considerations in this text will lead to answer the following research questions: which countries have implemented internet voting and if / how this form of voting affects voter turnout? In which countries (and why) the endeavors on the introduction of i-voting were suspended? What are the i-voting procedures in individual countries? What are the most important risks (threats) and benefits of voting over the Internet? What are the costs of the implementation of internet voting in certain countries?

Keywords: elections | Internet | voting over internet | i-voting

Słowa kluczowe: wybory | internet | głosowanie przez internet | i-głosowanie

\section{Wstęp}

W dobie dynamicznego rozwoju technologii informacyjnych i komunikacyjnych, szczególnie internetu, coraz częściej pojawiają się opinie mówiące, że tradycyjne sposoby uczestnictwa i głosowania w wyborach (w lokalu wyborczym) ze względu na utrudniony udział wielu uprawnionych (osób starszych, niepełnospraw-

\footnotetext{
Artykuł powstał w ramach projektu „E-voting jako alternatywna procedura głosowania w elekcjach państwowych. Doświadczenia wybranych państw a perspektywy wdrożenia e-głosowania w Polsce" - finansowanego przez NCN (konkurs OPUS, UMO-2014/15/B/HS5/0135).
} 
nych ruchowo, przebywających za granicą) winny być uzupełnione m.in. o formy głosowania elektronicznego. Stanowiska te są uzasadniane także poglądami na temat kryzysu demokracji, przejawiającego się głównie w obniżającym się poziomie frekwencji wyborczej. W związku z tym w wielu państwach podjęto kroki, by wprowadzić dodatkowe rozwiązania umożliwiające wyborcom udział w głosowaniu (np. advance voting) czy też alternatywne sposoby głosowania (głosowanie korespondencyjne, głosowanie przez pełnomocnika), a w innych wprowadzono lub rozważa się wprowadzenie do systemów głosowania innowacyjnych sposobów uczestnictwa opartych na elektronicznych środkach komunikacji.

Celem niniejszego artykułu jest analiza doświadczeń związanych $\mathrm{z}$ wdrożeniem i wykorzystaniem głosowania internetowego (jako formy głosowania elektronicznego) w wybranych państwach, gdzie głosowanie przez internet funkcjonuje lub gdzie wykorzystywano tę formę uczestnictwa w głosowaniach powszechnych. W opracowaniu postarano się udzielić odpowiedzi na następujące pytania badawcze: jakie państwa wdrożyły głosowanie internetowe i czy/jak ta forma głosowania wpływa na frekwencję wyborczą, w jakich państwach i dlaczego wstrzymano prace nad wprowadzeniem $i$-votingu, jakie są najważniejsze ryzyka (zagrożenia) i korzyści związane z głosowaniem przez internet? Postanowiono skoncentrować się na analizie doświadczeń pięciu państw, które wdrożyły lub zamierzały wdrożyć i-voting. Są to: Estonia, Szwajcaria, Stany Zjednoczone, Norwegia i Austria. Zaznaczyć przy tym należy, że dwa pierwsze państwa zdołały wprowadzić w życie głosowanie przez internet, dlatego poświęcono im najwięcej miejsca.

\section{Głosowanie internetowe}

Elektroniczne głosowanie (określane jako e-voting) jest jednym z tzw. alternatywnych sposobów głosowania i należy do narzędzi demokracji elektronicznej². E-voting w najprostszym ujęciu: oznacza głosowanie za pomoca środków elektronicznych ${ }^{3}$.

2 R. Krimmer, E-voting as a New Form of Voting, [w:] Explorations in eGovernment \& eGovernance. Volume 2: Selected proceedings of the Second International Conference on eGovernment and eGovernance, red. A. Balci, C. Can Actan, O. Dalbay, Antalya 2010, s. 148; M. Musiał-Karg, E-voting (as a form of E-democracy) in the European Countries [w:] Explorations in eGovernment \& eGovernance. Volume 2: Selected proceedings of the Second International Conference on eGovernment and eGovernance, red. A. Balci, C. Can Actan, O. Dalbay, Antalya 2010, s. 156-157.

3 A. Kaczmarczyk, R. Czajkowski, E-Głosowanie - niezbędny element elektronicznej platformy do obsługi procedur $w$ demokracji w społeczeństwie informacyjnym. E-vote an essential element of electronic platform for services for democratic procedures in the Information Society, referat prezentowany na konferencji „Tworzenie mechanizmów i struktur rozwoju elektronicznej gospodarki w Polsce”, Warszawa, 12 czerwca 2001 r., 
Technologiami wykorzystywanymi w procesach głosowania są przede wszystkim internet, telefonia, telewizja, platformy cyfrowe ${ }^{4}$.

Pod względem zastosowanych rozwiązań systemy e-głosowania można podzielić na cztery typy:

- maszyny do głosowania (Direct recording electronic voting machines, DRE) bez możliwości lub z możliwością druku potwierdzenia oddanego głosu (voter-verified paper audit trail, VVPAT); maszyny DRE z opcją VVPAT dostarczają fizycznych dowodów oddania głosu,

- systemy OMR (Optical Mark Recognition systems) bazują na wykorzystaniu specjalnych skanerów, które rozpoznają głosy oddane przez wyborców na specjalnych kartach do głosowania (dostosowanych do odczytu przez skanery); systemy OMR mogą funkcjonować jako:

- centralne systemy liczenia głosów - wówczas karty do głosowania są skanowane i liczone w specjalnych centrach przeliczania głosów, oraz jako

- systemy skanowania optycznego (precinct count optical scanning systems, PCOS) - wówczas skanowanie i przeliczanie kart do głosowania odbywa się w lokalu wyborczym, bezpośrednio po wprowadzeniu karty do głosowania (oddaniu głosu),

- drukarki głosów elektronicznych (Electronic ballot printers, EBPs) - urządzenia podobne do maszyn do głosowania, za pomocą których drukowane są specjalne karty (czytelne dla maszyn) lub znaczniki zawierające informację o wyborze dokonanym przez głosującego; takie głosy są dostarczane do skanowania i automatycznie przeliczane,

- systemy głosowania internetowego, w których głosy za pośrednictwem internetu przekazywane są do centralnego serwera zliczającego głosy; głosy oddawane mogą być zarówno z komputerów publicznych (maszyn do głosowania), tzw. kiosków wyborczych, jak i z dowolnego komputera z dostępem do internetu ${ }^{5}$.

W literaturze specjalistycznej głosowanie internetowe dzieli się najczęściej na dwie kategorie: głosowanie w lokalu wyborczym (Internet Voting at the Polling Place) lub głosowanie zdalne (Remote Internet Voting). W tym pierwszym wyborcy oddają głos w specjalnie do tego przygotowanym kiosku wyborczym z wykorzystaniem kanału, jakim jest internet. Natomiast Remote Internet Voting jest zdalnym sposobem oddawania głosu, dzięki któremu wyborca głosuje bądź

s. 50, http://www.logistyka.net.pl/images/articles/1375/Ref-Czajkowski.doc [dostęp 13 października 2017 r.].

4 M. Nowina-Konopka, Elektroniczna urna, http://www.rpo.gov.pl/pliki/12066058070. pdf [dostęp 15 września 2012 r.].

5 Introducing Electronic Voting: Essential Considerations, International Institute for Democracy and Electoral Assistance (International IDEA), Policy Paper, December 2011, s. 10-11. 
to z kiosku wyborczego (tyle że znajdującego się poza lokalem wyborczym), bądź $\mathrm{z}$ dowolnego komputera podłączonego do internetu. Internetem przesyłane są dane do centralnej bazy danych z każdego z wymienionych typów stanowisk.

Na rysunku 1 przedstawiono wybrane mocne i słabe strony trzech sposobów głosowania przez internet: głosowania internetowego za pomocą maszyn do głosowania umiejscowionych w lokalu wyborczym, za pomocą kiosku wyborczego znajdującego się poza lokalem wyborczym oraz za pomocą zdalnego głosowania online ( $\mathrm{z}$ komputera lub telefonu komórkowego).

Pierwszy sposób głosowania internetowego - w lokalu wyborczym - gwarantuje wysoki poziom kontroli, zapewnia duży stopień bezpieczeństwa, ale jednocześnie $\mathrm{w}$ porównaniu z dwiema pozostałymi formami jest mniej dostępną metodą dla elektoratu (wyborca, żeby zagłosować, musi pójść do konkretnego lokalu wyborczego). W przypadku zdalnego głosowania z kiosku wyborczego zapewniony jest umiarkowany poziom kontroli (mniejszy niż w lokalu wyborczym), wysoki poziom bezpieczeństwa, a dodatkowo - kiosk wyborczy jest nieco bardziej dostępny dla przeciętnego wyborcy. Nadmienić warto, że sposób ten może generować więcej problemów technicznych w porównaniu z i-głosowaniem w lokalu wyborczym.

\section{Rysunek 1. Sposoby głosowania internetowego}

- wysoki poziom kontroli

- bardzo wysoki poziom zabezpieczenia

Głosowanie internetowe w lokalu wyborczym Polling Place Internet Voting

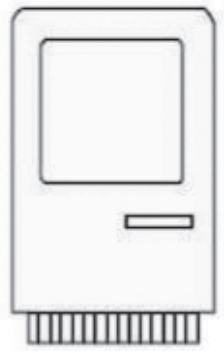

niska dostępność
- umiarkowany poziom kontroli

- wysoki poziom zabezpieczenia

Zdalne głosowanie internetowe w kiosku Remote Kiosk Internet Voting

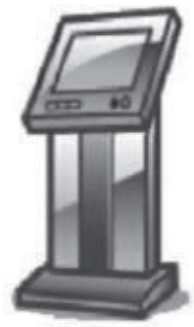

umiarkowana dostępność
- niski poziom kontroli

- umiarkowany poziom zabezpieczenia

Zdalne głosowanie internetowe; głosowanie telefoniczne Remote Internet Voting /Mobile Phone Voting

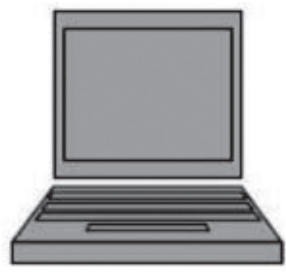

duża dostępność res\&dir=rec/tech/ivote/comp\&document=description\&lang=e\#fg1 [dostęp 11 października 2017 r.]. 
Zdalne głosowanie internetowe przeprowadzone za pomocą komputera czy telefonu komórkowego wydaje się być sposobem mniej narażonym na różnego rodzaju problemy techniczne (choćby z powodu małej liczby użytkowników jednego urządzenia - głosowanie za pośrednictwem komputera czy telefonu przeprowadza zwykle jego właściciel). Takie głosowanie z perspektywy wyborcy może być dokonane o dowolnej porze $\mathrm{z}$ dowolnego miejsca ${ }^{6}$. Zauważyć należy, że Remote Internet Voting gwarantuje jednocześnie o wiele niższy poziom kontroli, co z kolei może negatywnie przekładać się na poziom bezpieczeństwa (narażenie komputera osobistego na ataki hakerskie).

Głosowane internetowe może być wykorzystane przy wyborach (i-wybory/ i-election) oraz w referendach (i-referendum), co odpowiada rozróżnieniu między formami demokracji przedstawicielskiej i bezpośredniej. Pod względem technologicznym ten drugi rodzaj głosowania wydaje się mniej skomplikowany do zastosowania - głównie ze względu na zwykle dwie możliwe odpowiedzi w głosowaniu („Tak” lub „Nie”). W przypadku wyborów karta do głosowania jest najczęściej bardziej skomplikowana i obszerniejsza co do treści niż karta referendalna.

Rozpatrując wprowadzenie dowolnej formy e-głosowania (także $i$-voting), należy uwzględnić fakt, że w zależności od wybranej formuły głosowanie może być przeprowadzone w tzw. środowisku kontrolowanym lub niekontrolowanym.

O i-głosowaniu w środowisku kontrolowanym mówi się wówczas, gdy oddawanie głosów następuje w lokalu wyborczym, kiosku wyborczym lub innym miejscu nadzorowanym przez personel reprezentujący organ zarządzający wyborami. Oznacza to, że tzw. administracja wyborcza może w dużym stopniu kontrolować procedury wyborcze, warunki, w jakich wyborcy oddają swoje głosy, oraz same technologie głosowania. Głosowanie internetowe w środowisku kontrolowanym może być zatem uznane za odpowiednik tradycyjnego głosowania na papierowych kartach wyborczych w lokalu wyborczym. Z kolei głosowanie internetowe $\mathrm{w}$ środowisku niekontrolowanym polega na oddaniu głosu w warunkach bez nadzoru przedstawicieli administracji wyborczej jak i bez kontroli urządzeń, za pomocą których oddawane są głosy. Wyborca może zatem oddać głos z dowolnego komputera lub z innego urządzenia przenośnego (smartfon, tablet), mającego dostęp do internetu ${ }^{7}$.

Obawy związane z głosowaniem w niekontrolowanym środowisku dotyczą przede wszystkim kwestii zagwarantowania tajności głosowania, oddawania głosów za kogoś z rodziny, zastraszania wyborców, kupowania głosów. Jednym $\mathrm{Z}$ argumentów przeciwników takich form głosowania jest także utrata rytuałów

6 A Comparative Assessment of Electronic Voting, http://www.elections.ca/content. aspx? section=res\&dir=rec/tech/ivote/comp\&document=description\&lang=e\#fg1 [dostęp 11 października 2017 r.].

7 Introducing Electronic Voting: Essential, op. cit., s. 10-11. 
związanych z dniem wyborczym. Ponadto wysuwane są argumenty, mówiące o negatywnym wpływie na wybory przepaści cyfrowej (digital divide) i technicznego oddzielenia tożsamości wyborcy od karty do głosowania.

I-głosowanie może być wprowadzone jako jedyny kanał głosowania dostępny dla wyborców lub może być oferowany jako dodatkowy sposób głosowania. Głosowanie za pomocą internetu jest powszechnie wprowadzane jako kanał alternatywny, podczas gdy maszyny głosujące są najczęściej wprowadzane jako jedyny kanał głosowania dostępny dla wyborców w lokalu wyborczym.

\section{Państwa, które mają doświadczenia związane z i-votingiem}

Zgodnie z danymi Competence Center for Electronic Voting and Participation (E-Voting.CC $\mathrm{GmbH}$ ) tylko kilka państw na świecie stosuje (lub jest na bardzo zaawansowanym etapie wdrażania) tzw. Remote Internet Voting. Zaznaczyć należy, że we wszystkich przypadkach $i$-voting stanowi dodatkową, alternatywną wobec głosowania tradycyjnego i korespondencyjnego formę uczestnictwa w wyborach oraz referendach.

\section{Estonia}

Światowym liderem, jeśli chodzi o wykorzystanie elektronicznego głosowania w wyborach, jest Estonia. Obywatele tego małego państwa od 2005 r. mają możliwość głosowania za pomocą internetu ${ }^{8}$.

Na szczeblu rządowym dyskusja o implementacji elektronicznego głosowania w Estonii rozpoczęła się w 2001 r. Rok później estoński parlament - Zgromadzenie Państwowe (Riigikogu) - stworzył podstawy prawne do przeprowadzenia głosowania przez internet ${ }^{9}$. Latem 2003 r. Państwowa Komisja Wyborcza w Estonii zaczęła wdrażać projekt systemu i-głosowania ${ }^{10}$. W styczniu 2000 r. weszła

8 M. Musiał-Karg, Internetowe głosowanie w E-stonii na przykładzie wyborów w latach 2005-2009, „Przegląd Politologiczny” 2011, nr 3, s. 98-111.

9 Digital Signature Act 2002 - ustawa pozwala obywatelom używać przyjętych podpisów elektronicznych w celu potwierdzania tożsamości w transakcjach online, a także w głosowaniu; N. Goodman, J.H. Pammett, J. DeBardeleben, J. Freeland, A Comparative Assessment of Electronic Voting, Strategic Knowledge Cluster Canada-Europe Transatlantic Dialogue, Carlton University, February 2010, s. 33, https://www.elections.virginia.gov/Files/Media/SB11Workgroup/SB11DraftSept3v1-APPX.pdf [dostęp 10 października 2017 r.].

10 E. Maaten, Towards remote e-voting: Estonian case, Elections Departament. Chancellery of the Riigikogu (Parliament), Tallin 2004, materiały konferencyjne $\mathrm{z}$ The International Workshop on Electronic Voting in Europe, Bregenz/Austria, 7-9 lipca 2004 r., s. 83, https://pdfs.semanticscholar.org/ff4d/0a77e7561e62fd0258280c0baa02 d8256a03.pdf [dostęp 10 października 2017 r.]. 
w życie ustawa dotycząca nowych dowodów osobistych (Identity Documents Act), wprowadzając od 2002 r. obowiązek posiadania eID-card ${ }^{11}$. Takie dowody osobiste, wydawane przez rząd Estonii od 2002 r., mają dwojakie funkcje: oprócz tego, że są dokumentami identyfikacyjnymi, służą również do potwierdzania tożsamości elektronicznej.

Aby oddać głos przez internet, estoński wyborca potrzebuje: dowodu osobistego nowej generacji z ważnymi certyfikatami (odnawianymi na stronie www), kodów PIN (wydawanych razem z kartami eID) oraz komputera wyposażonego w czytnik kart eID (wraz z odpowiednim oprogramowaniem - instalacja installer.id.ee/), połączenia $\mathrm{z}$ internetem oraz systemu operacyjnego Windows, MacOS lub Linux ${ }^{12}$. Od 2011 r. do uwierzytelnienia możliwe są także rozwiązania mobilne - Mobile-ID solution.

Jedną z najważniejszych kwestii ustalonych przy wdrażaniu systemu i-głosowania był fakt, że głosowanie elektroniczne musi być tak podobne do głosowania tradycyjnego jak to tylko możliwe. Oprócz tego warunkiem wprowadzenia w życie $i$-votingu była zgodność głosowania z prawem i zasadami wyborów, a także to, by i-głosowanie było co najmniej w takim stopniu bezpieczne jak oddawanie głosów w sposób tradycyjny ${ }^{13}$.

Zgodnie $\mathrm{z}$ estońskim prawem wyborczym ${ }^{14}$ i-głosowanie odbywa się od 10 . do 4. dnia przed dniem wyborów. Taki rozkład w czasie, tzw. advance voting, jest potrzebny, by zagwarantować czas niezbędny do wyeliminowania podwójnych głosów do dnia wyborów. By zapewnić wyborcy oddanie głosu zgodnego z jego wolą, wyposaża się go w możliwość zmiany głosu elektronicznego przez ponowne zagłosowanie (jeszcze przed dniem wyborów) lub przez zagłosowanie w lokalu wyborczym (również przed dniem wyborów).

System i-głosowania w Estonii oparty jest na „metodzie podwójnej koperty” wykorzystywanej zwykle w głosowaniu korespondencyjnym (rysunek 2).

Jak wspomniano, w Estonii istnieje możliwość ponownego elektronicznego głosowania w wyborach - wyborca w czasie advance voting może oddać głos po raz kolejny, a poprzednio oddany głos zostaje wówczas anulowany. W tym kontekście niezwykle istotna jest zasada traktowania głosowania tradycyjnego jako priorytetowego. Gdy wyborca, który zagłosował wcześniej elektronicznie,

11 W 2005 r. posiadacze nowych eID cards stanowili około 900 tys.; Estonian National Electoral Committee, http://www.vvk.ee/index.php?id=11178\&tpl=1062 [dostęp 10 października 2017 r.].

12 Ibidem.

13 E-Voting System. General Overview, Estonian National Electoral Committee, Tallin 2005-2010, s. 7.

14 Riigikogu Election Act, Local Government Council Election Act, Referendum Act and European Parliament Election Act - wszystkie ustawy zawierają podobne warunki e-głosowania. 


\section{Rysunek 2. Metoda podwójnej koperty w i-głosowaniu w Estonii}

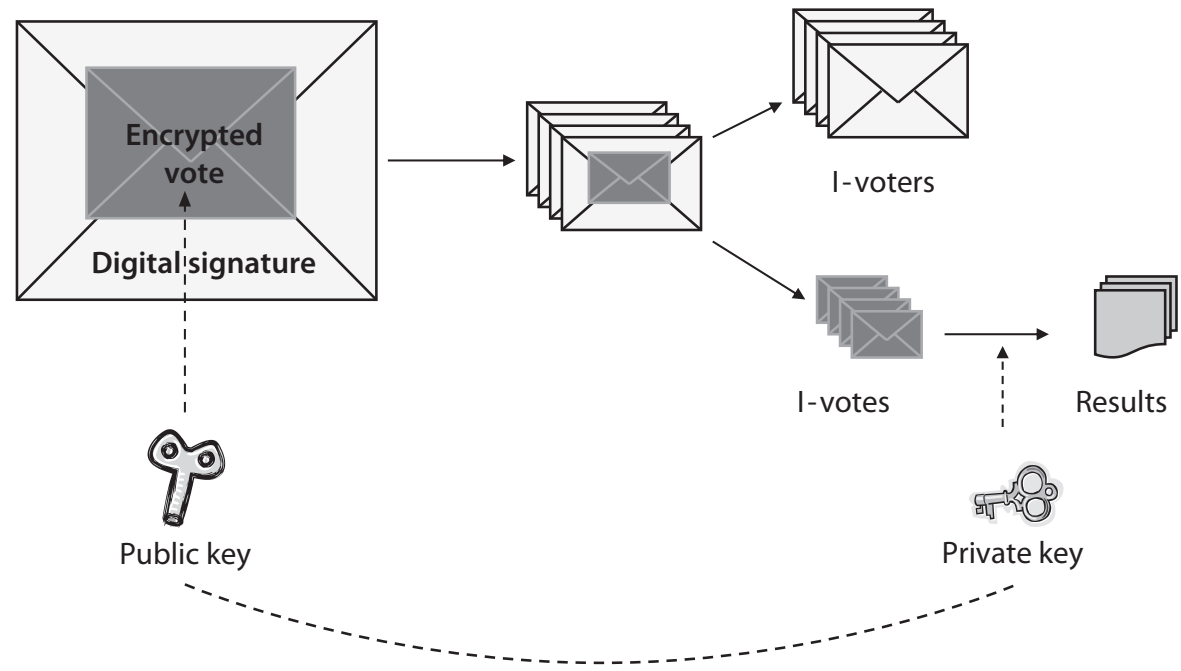

Źródło: T. Martens, Internet Voting in Estonia, National Electoral Committee, Prezentacja PPT, https:// www.valimised.ee/sites/default/files/uploads/eng/EH_Overiview_03-11.pdf [dostęp 11 października 2017 r.].

w dniu głosowania tradycyjnego pójdzie do lokalu wyborczego i tam odda głos, jego elektroniczny głos zostaje anulowany.

Z technicznego punktu widzenia wymagane jest, by system elektronicznego (internetowego) głosowania w Estonii był tak prosty jak to tylko możliwe, a także tak transparentny, by specjaliści od tego typu przedsięwzięć mogli sprawdzać jego funkcjonowanie. Zgodnie z przyjętymi w Estonii założeniami system i-głosowania musi być także przeznaczony do wielokrotnego stosowania - chodzi o to, by przy kolejnych wyborach nie istniała potrzeba opracowywania nowego systemu opartego na metodach elektronicznych ${ }^{15}$.

Warto zwrócić także uwagę na motywacje wdrożenia i-głosowania w Estonii. Jako najważniejsze przyczyny wymienić należy: udostępnienie dodatkowego i wygodnego kanału oddawania głosu, a przez to unowocześnienie głosowania,

15 Jeśli chodzi o sam akt wyborczy, to należy pamiętać, że zaangażowane w niego są zawsze dwie strony: wyborca oraz odbiorca głosu. W głosowaniu elektronicznym natomiast tymi stronami są komputer wyborcy oraz serwery prowadzone przez Państwową Komisję Wyborczą (National Electoral Committee, NEC) i pod jej nadzorem. Najsłabszym ogniwem procedury e-głosowania jest zapewne będący własnością wyborcy - komputer, nad którym nie ma kontroli. Mimo że serwery NEC mogą być kontrolowane, to pojawiające się błędy czy ataki mogą wpłynąć na dużą liczbę głosów jednocześnie. System e-głosowania traktuje te kwestie bardzo poważnie, E-Voting System. General Overview, op. cit., s. 8. 
a także umożliwienie bardziej wydajnego wykorzystania istniejącej infrastruktury (cyfrowe platformy oraz elektroniczne eID-karty). W przeciwieństwie do licznych stwierdzeń pojawiających się w opinii publicznej, zwiększenie frekwencji wyborczej nie było celem wdrożenia $i$-votingu w Estonii. Jednak w wielu pracach dotyczących i-głosowania zwraca się uwagę na kwestie jego wpływu na poziom frekwencji w wyborach.

Tabela 1. I-wybory w Estonii - zestawienie wybranych danych

\begin{tabular}{|c|c|c|c|c|c|c|c|c|}
\hline Wybory & 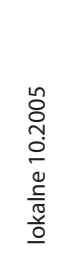 & 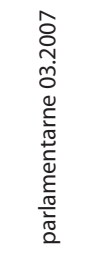 & 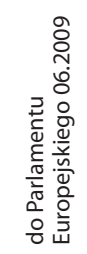 & 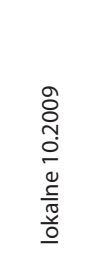 & 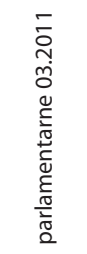 & 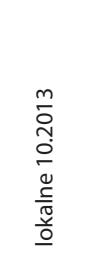 & 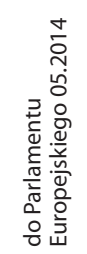 & 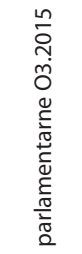 \\
\hline Frekwencja (\%) & 47,43 & 61,91 & 43,88 & 60,6 & 63,5 & 58,0 & 36,5 & 64,2 \\
\hline $\begin{array}{l}\text { I-frekwencja (\%), i-głosy } \\
\text { w stosunku do wszystkich } \\
\text { uprawnionych }\end{array}$ & 0,91 & 3,46 & 6,54 & 9,5 & 15,4 & 12,3 & 11,4 & 19,6 \\
\hline $\begin{array}{l}\text { Udział i-głosów w stosunku } \\
\text { do wszystkich oddanych } \\
\text { głosów (\%) }\end{array}$ & 1,85 & 5,44 & 14,68 & 15,74 & 24,3 & 21,2 & 31,3 & 30,5 \\
\hline $\begin{array}{l}\text { I-głosy wśród wszystkich } \\
\text { głosujących przed dniem } \\
\text { wyborów (advanced voting) }\end{array}$ & 7,2 & 17,6 & 45,4 & 44 & 56,4 & 50,5 & 59,2 & 59,6 \\
\hline $\begin{array}{l}\text { l-głosy z zagranicy w stosun- } \\
\text { ku do wszystkich i-głosów }\end{array}$ & b.d. & $\begin{array}{c}2 \% \\
51 \\
\text { państw }\end{array}$ & $\begin{array}{l}3 \% \\
66 \\
\text { państw }\end{array}$ & $\begin{array}{c}2,8 \% \\
82 \\
\text { państwa }\end{array}$ & $\begin{array}{l}3,9 \% \\
105 \\
\text { państw }\end{array}$ & $\begin{array}{l}4,2 \% \\
105 \\
\text { państw }\end{array}$ & $\begin{array}{l}4,69 \% \\
89 \\
\text { państw }\end{array}$ & $\begin{array}{l}5,71 \% \\
116 \\
\text { państw }\end{array}$ \\
\hline Okres i-głosowania & $3 \mathrm{dni}$ & $3 \mathrm{dni}$ & $7 \mathrm{dni}$ & $7 \mathrm{dni}$ & $7 \mathrm{dni}$ & $7 \mathrm{dni}$ & $7 \mathrm{dni}$ & $7 \mathrm{dni}$ \\
\hline
\end{tabular}

Źródło: na podstawie danych Estonian National Electoral Committee, http://www.vvk.ee/voting-methods-in-estonia/engindex/statistics [dostęp 10 października 2017 r.].

Analizując wyniki kolejnych wyborów w Estonii (lokalnych, parlamentarnych czy wyborów do Parlamentu Europejskiego), łatwo dojść do wniosku, że i-głosowanie zyskuje na popularności i coraz więcej wyborców uczestniczących w poszczególnych elekcjach decyduje się na oddanie głosów za pośrednictwem internetu. Dowodzą tego dane zaprezentowane w tabeli 1.

Przyglądając się skali udziału Estończyków w wyborach, zauważyć można, że o ile w wyborach do Parlamentu Europejskiego frekwencja wyborcza istotnie zmalała, o tyle w wyborach lokalnych wzrost partycypacji od roku 2005 jest zauważalny. W przypadku zaś wyborów parlamentarnych odnotowano wzrost frekwencji odpowiednio o 2\% w roku 2011 (w stosunku do pierwszego i-głosowania w 2007 r.) oraz o 1\% w 2015 (w stosunku do wyniku z 2011 r.). Trudno jednak formułować jednoznaczną opinię, że i-głosowanie przekłada się na wzrost frekwencji. Odnotowuje się wzrost udziału obywateli w wyborach lokal- 
nych i parlamentarnych, jednak specjaliści są ostrożni w formułowaniu wniosków w tym obszarze ${ }^{16}$.

Podsumowując, stwierdzić należy, że na sukces w zakresie wdrożenia i funkcjonowania i-głosowania w Estonii miały wpływ następujące czynniki:

- porozumienie na szczeblu politycznym co do implementacji i-głosowana,

- współpraca sektora prywatnego i publicznego w zakresie opracowania syste$\mathrm{mu}$,

- szerokie wykorzystanie ID-kart (wraz z bezpiecznym uwierzytelnieniem),

- odpowiednie koszty: rozwój i implementacja w ciągu 4 lat - 400 tys. euro (koszty wdrożenia $i$-votingu w stosunku do całego budżetu wyborczego (20\% w 2005 r. i $6 \%$ w 2007 r. $)^{17}$.

\section{Szwajcaria ${ }^{18}$}

Szwajcaria jest kolejnym przykładem państwa europejskiego, które jako jedno z pierwszych rozpoczęło proces zmierzający do implementacji głosowania opartego na wykorzystaniu nowych technologii. Helwecki rząd rozpoczął proces wdrażania e-voting $u^{19}$ (a precyzyjniej - i-votingu) w roku $1998^{20}$.

Do 2015 r. w Konfederacji Szwajcarii wdrażane były trzy projekty pilotażowe - Genewa, Neuchâtel i Zurych ${ }^{21}$. Kluczowy jest fakt, że Vote électronique (bo taka jest oficjalna nazwa całego projektu) był wspólnym projektem Konfederacji i kantonów. Pierwsze próby z i-votingem rozpoczęły się w 2003 r. w Genewie, a następnie w Neuchâtel i Zurychu. W 2008 r. głosowanie online zostało rozszerzone na obywateli szwajcarskich mieszkających za granicą, najpierw w Genewie, a potem w pozostałych kantonach ${ }^{22}$. Do 2015 r. łącznie 13 kantonów (tworząc konsorcja) testowało trzy szwajcarskie systemy. Na krótko przed wyborami parlamentarnymi w 2015 r. system Zurychu nie przeszedł audytu bezpieczeństwa.

16 M. Solvak, K. Vassil, E-voting in Estonia: Technological Diffusion and Other Developments Over Ten Years (2005-2015), University of Tartu \& Estonian National Electoral Committee, Tartu 2016.

17 P. Vinkel, Internet Voting in Estonia, http://www.eis.fi/tapahtumat/2008/Seminaari200809/Finnish_delegation_Internet_voting.pdf [dostęp 10 października 2017 r.].

18 Szerzej na temat e-votingu w Szwajcarii zob. M. Musiał-Karg, Elektroniczne referendum w Szwajcarii. Wybrane kierunki zmian helweckiej demokracji bezpośredniej, Poznań 2012.

19 W związku z tym, że projekty szwajcarskie w swoich oficjalnych nazwach miały słowo „e-voting”, autorka w przypadku szwajcarskich doświadczeń używa zamiennie określeń e-głosowanie oraz i-głosowanie.

20 D. Braendli, The scope of e-voting in Switzerland, E-Voting and Electronic Democracy: Present and the Future - An International Conference, Seoul, South Korea, March 17-18 2005, s. 2.

${ }^{21}$ Projekty w różnym zakresie uwzględniają wykorzystanie nowoczesnych technologii. Umożliwiają głosowanie w wyborach i referendach m.in. za pomocą internetu, ale i SMSa.

22 M. Musiał-Karg, Elektroniczne referendum w Szwajcarii, op. cit., s. 188-228. 
Dziewięć kantonów, które wybrało Zurych E-voting System, rozwiązało konsorcjum i zawiesiło dalsze prace nad wdrażaniem tego systemu ${ }^{23}$.

Funkcjonujące w Szwajcarii trzy systemy głosowania elektronicznego (internetowego) - Zurych, Genewa, Neuchâtel - różniły się między sobą strukturą, jednak najważniejsze kroki (etapy) przy oddawaniu głosów za pośrednictwem tych systemów wyglądały bardzo podobnie. Dysponując dokumentem uprawniającym do głosowania (na którym zamieszczone są dane do głosowania elektronicznego), wyborca po wpisaniu swojego identyfikatora (ID użytkownika) lub numeru karty do głosowania wybierał właściwą odpowiedź na pytanie referendalne, następnie wpisywał z karty do głosowania elektronicznego kod PIN i utajnione pod „zdrapką” hasło, a na końcu wysyłał głos. Procedurę kończyło otrzymanie informacji, potwierdzającej oddanie głosu.

Pierwszoplanowym celem wprowadzania $e$-votingu w Konfederacji Szwajcarskiej było dostarczenie uprawnionym obywatelom dodatkowej platformy do oddawania głosów w referendach i wyborach oraz umożliwienie w przyszłości składania tzw. elektronicznego podpisu przy okazji składania wniosków związanych $\mathrm{z}$ inicjatywą ludową, referendum czy zgłaszaniem kandydatów przed wyborami parlamentarnymi. Za najważniejszą grupę wyborców potencjalnie zainteresowanych wprowadzaniem e-votingu uznano ludzi młodych korzystających $\mathrm{z}$ internetu (wcześniej zazwyczaj nieuczestniczących w głosowaniach) oraz wyborców, którzy nie są zdolni do uczestnictwa w głosowaniach (ze względu np. na ograniczenia natury fizycznej). Ważną grupę docelową stanowią obywatele Szwajcarii, którzy przebywają poza granicami państwa.

Dodać należy, że każdy z wdrażanych w Szwajcarii projektów udostępniał demonstracyjną wersję procedury głosowania. Po wejściu na odpowiednie strony internetowe: systemu genewskiego - www.ge.ch.evoting, systemu zuryskiego - www. evotingdemo.zh.ch, systemu Neuchâtel - www.guichetunique.ch, kierując się instrukcjami podawanymi na stronie internetowej, można przejść całą procedurę głosowania.

W Geneva E-voting System ${ }^{24}$ głosowanie internetowe odbywa się w czterech etapach.

- Aby uzyskać dostęp do serwera wyborczego, wyborca musi wpisać do systemu 16-cyfrowy numer ważnej karty do głosowania ${ }^{25}$.

23 U. Serdült, The Swiss Experience with Internet Voting, The Centre for E-Democracy, 2016, http://www.centreforedemocracy.com/wp-content/uploads/2016/10/Policy_ Brief_Uwe_Serduit.pdf [dostęp 11 października 2017 r.].

24 A. Weber, G. Taglioni, Swiss Elections to the National Council: First trials with e-voting in elections at federal level, Dagstuhl-Seminar 11281: Verifiable Elections and the Public (10-15.07.2011), s. 3, http://arxiv.org/ftp/arxiv/papers/1109/1109.2489.pdf [dostęp 12 listopada 2012 r.].

25 Warto nadmienić, że karta do głosowania podzielona jest na dwie części: lewa strona służy do głosowania online, natomiast strona prawa - do głosowania tradycyjnego lub korespondencyjnego. 


\section{Rysunek 3. Kolejne etapy głosowania elektronicznego}

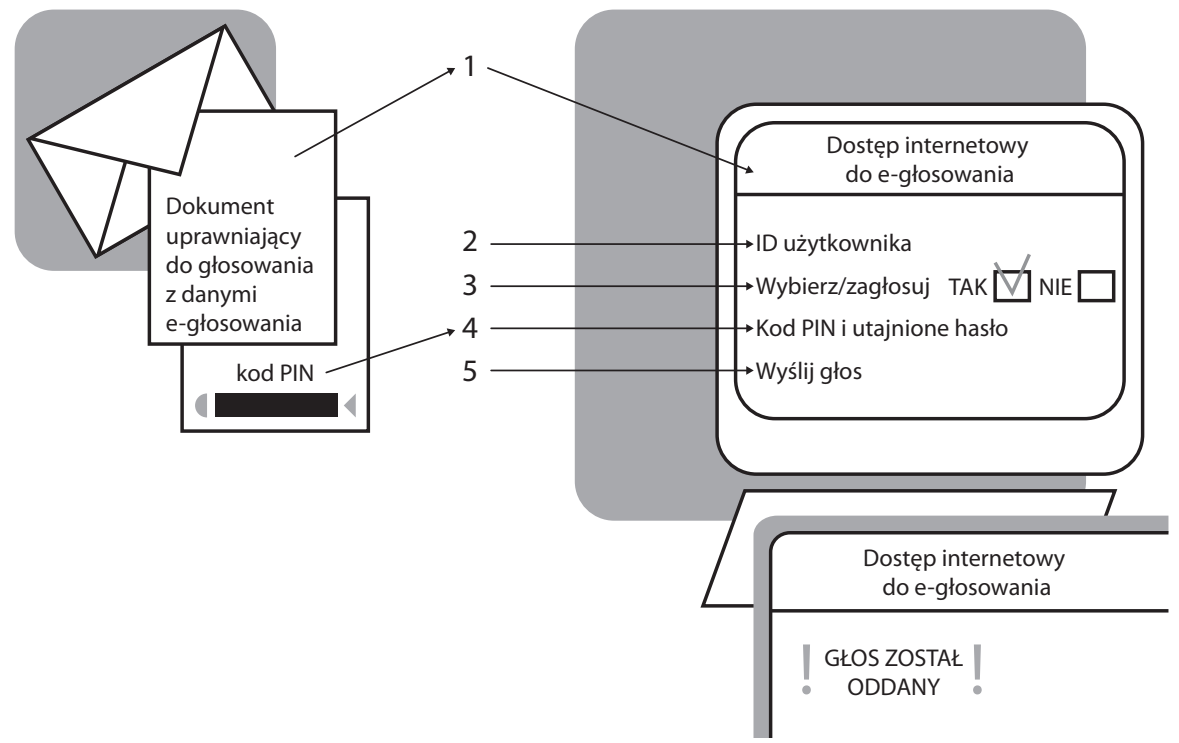

Źródło: E-voting. Wspólny projekt federalno-kantonalny, broszura informacyjna nt. e-votingu, Bundeskanzler, Berno 2012, s. 12-13.

\section{Rysunek 4. Głosowanie za pośrednictwem Geneva E-voting System}

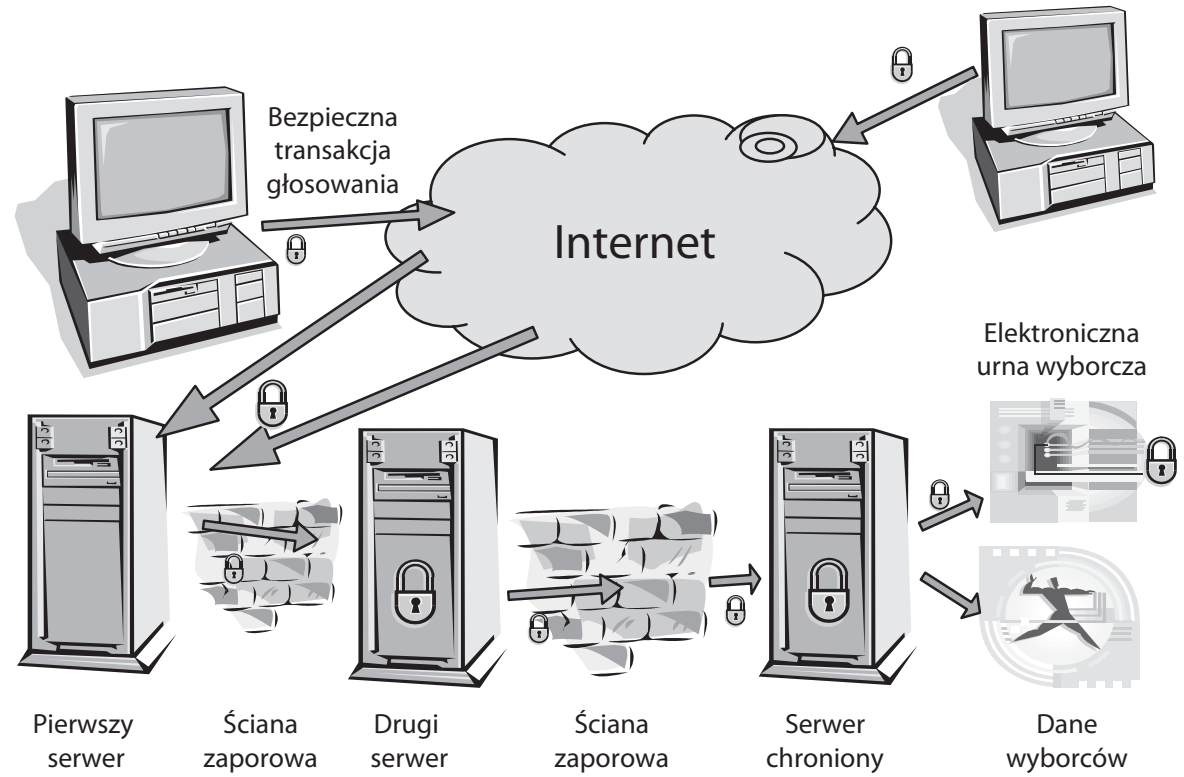

Źródło: M. Chevalier, Internet voting: Status, Perspectives and Issues, prezentacja podczas warsztatów ITU E-Government, Genewa, lipiec 2003 r., http://www.itu.int/itudoc/itu-t/workshop/e-gov/e-gov010.pdf [dostęp 11 października 2017 r.]. 


\section{Grafika 1. Karta do głosowania}

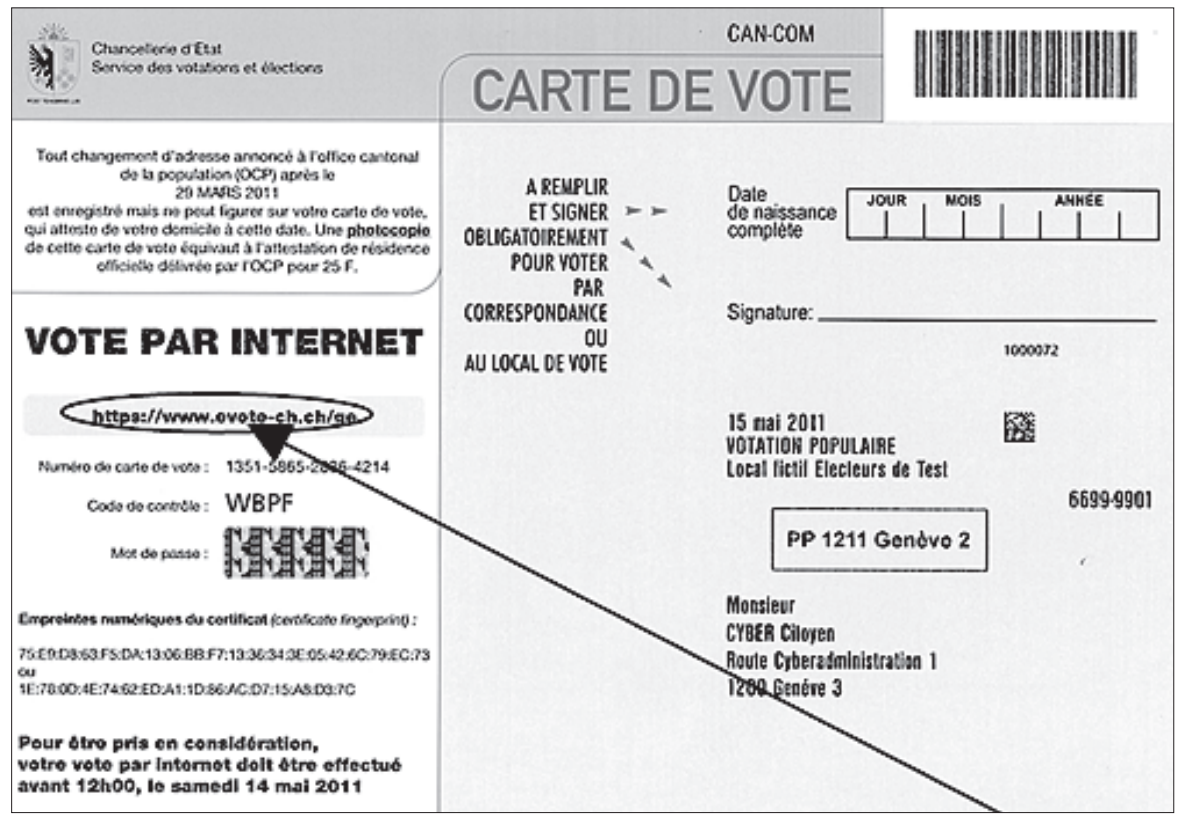

Źródło: E-voting, Republique et Canton de Geneve, http://ge.ch/vote-electronique/actualites/votation-8-mars-vote-electronique-electeurs-prennent-controle [dostęp 13 października 2017 r.].

- Wyborca oddaje głos, zaznaczając kwadrat z odpowiedzią „Tak” lub „Nie”.

- System wymaga od wyborcy potwierdzenia dokonanych wyborów. Za pomocą kodu kontrolnego wyborca może sprawdzić, czy jego głos został uwzględniony $\mathrm{w}$ systemie. Następnie wyborca jest proszony o dokonanie uwierzytelnienia przez wpisanie daty urodzenia, miejsca pochodzenia, kodu identyfikacyjnego z karty wyborczej (który ukryty jest pod tzw. zdrapką ${ }^{26}$ ).

- System potwierdza, że zarejestrował głos (informacja z datą i godziną rejestracji) ${ }^{27}$.

Schemat głosowania w kantonie Zurych przedstawiono na rysunku 5. Właścicielem oprogramowania stosowanego w Zurich E-voting System był kanton Zurych, natomiast przedsięwzięcie od strony technicznej obsługiwała firma zewnętrzna ${ }^{28}$.

26 Zdrapka to technika pokrywania papieru lub kuponu specjalną warstwą ochronną. Powierzchnia do zdrapania zakrywa kod lub symbol, który nie jest możliwy do odczytu bez usunięcia warstwy ochronnej.

27 State Council's Report to the Grand Council on the Geneva electronic voting project, Republic and Canton of Geneva, State Chancellery, 2007, s. 21-22.

28 A. Weber, G. Taglioni, Swiss Elections to the National, op. cit., s. 3. 


\section{Rysunek 5. Głosowanie za pośrednictwem Zurich E-voting System}

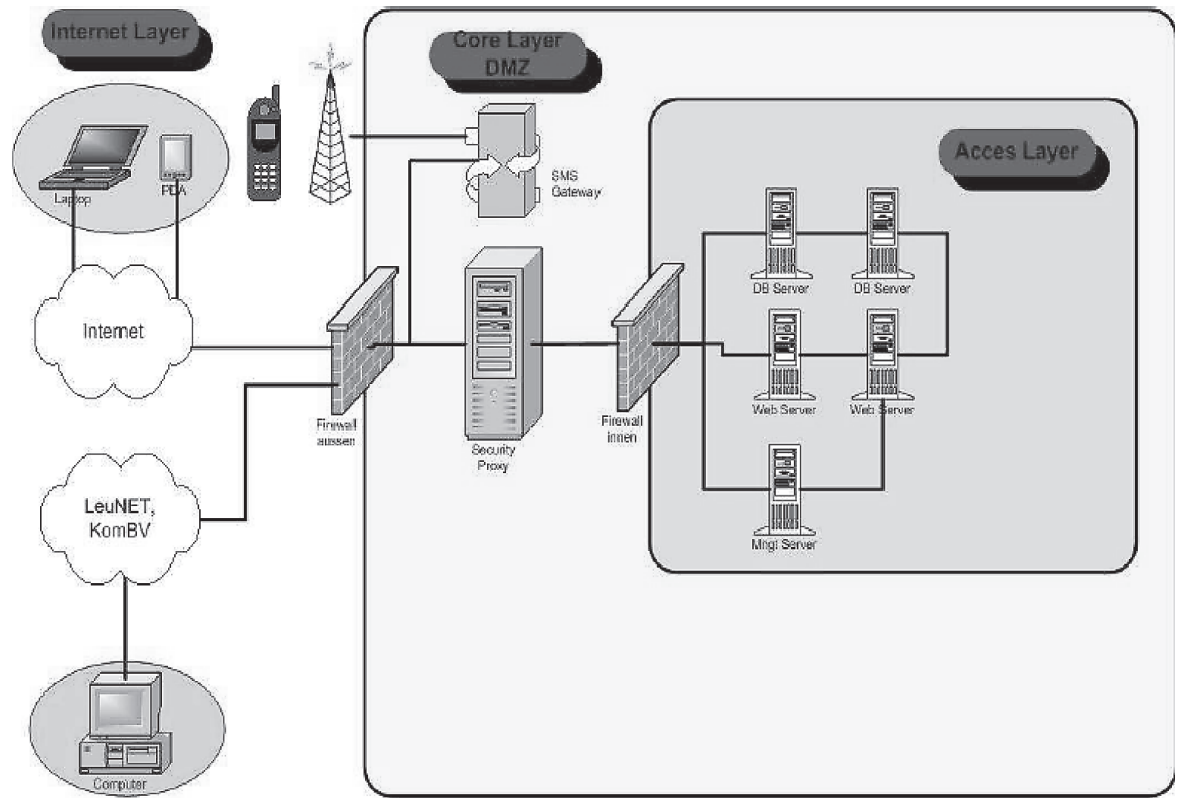

Źródło: Statistiches Amt des Kantons Zürich.

Z punktu widzenia wyborcy procedura głosowania elektronicznego w kantonie Zurych jest bardzo zbliżona do tej z kantonu Genewa. Dodać warto, że początkowo w pakiecie wyborczym znajdowało się również zestawienie kodów SMS, które mogły być wykorzystane przy głosowaniu za pośrednictwem telefonu komórkowego. Z głosowania telefonicznego zrezygnowano ze względu na małe zainteresowanie wyborców.

Cały proces pilotażu zaplanowany został na około cztery lata. Głosowania pilotażowe, wykorzystujące internet, zostały zakończone sukcesem wiosną roku 2006. Swisscom Solutions, szwajcarska wiodąca firma telekomunikacyjna, wprowadzała system oraz prowadziła wewnętrzny audyt pod względem bezpieczeństwa głosowań. Kancelaria Federalna równolegle prowadziła oddzielny audyt.

Koszt całego przedsięwzięcia wyniósł 3,7 mln dolarów: 1,9 mln dolarów wydano na planowanie i opracowanie, a 1,8 mln dolarów przeznaczono na implementację systemu. Niezmiernie istotny wydaje się fakt, że coroczne koszty operacyjne związane z e-votingiem szacowane są na kwotę 400 tys. dolarów, co w przeliczeniu daje 0,5 dolara na jeden elektronicznie oddany głos ${ }^{29}$.

Zaznaczyć należy, że procedura e-głosowania w ramach platformy internetowej Guichet unique - podobnie jak w pozostałych kantonach - zbliżona była do

29 G.E.G. Beroggi, Secure and Easy Internet Voting, „Computer” 2008, t. 41, nr 2, s. 52. 
systemu bankowości internetowej. Cały system $e$-voting w Neuchâtel pod względem różnego rodzaju zabezpieczeń (kryptografii i certyfikatów) podobny jest do projektu wdrażanego w kantonie Genewa ${ }^{30}$.

Po problemach z zapewnieniem bezpieczeństwa w systemie $i$-votingu kantonu Zurych wstrzymano także prace nad systemem Neuchâtel. Na poziomie Konfederacji postanowiono dalej pracować nad systemem genewskim oraz nad nowym systemem e-głosowania oferowanym przez Swiss Post $^{31}$.

Obecnie sześć kantonów prowadzi testy i-głosowania. W trzech kantonach e-voting jest oferowany tylko wyborcom szwajcarskim zamieszkałym za granicą. Kantony Genewa i Neuchâtel umożliwiają i-głosowanie także części wyborców mieszkających w kraju. W kantonie Bazylea-Stadt - od dnia 5 czerwca 2016 r. nie tylko Szwajcarzy mieszkający za granicą, ale także osoby niepełnosprawne mieszkające w kantonie mogą korzystać z i-głosowania

Podsumowując, stwierdzić należy, że do tej pory 14 kantonów w różnym czasie umożliwiało Szwajcarom mieszkającym za granicą internetowe głosowanie. Trzy kantony (Neuchâtel, Genewa i Bazylea-Stadt) prowadziły systemy głosowania elektronicznego dla mieszkańców Szwajcarii. Statystyki wskazują, że około $60 \%$ obywateli, którzy mieli prawo głosować drogą elektroniczną, skorzystało $\mathrm{z}$ tej możliwości.

Obecnie szwajcarskie prawo stawia ograniczenia liczbowe co do i-głosowania: dopuszcza się umożliwienie składania maksymalnie 10\% i-głosów w referendach i 30\% w przypadku głosowań powszechnych nad poprawkami konstytucyjnymi. Obecnie Swiss Post i kanton Genewa oferują i testują systemy głosowania internetowego, które mogłyby być wykorzystane w Szwajcarii ${ }^{32}$.

\section{USA}

Idea przeprowadzenia wyborów całkowicie za pośrednictwem internetu w najbliżej przyszłości nie jest rozważana w Stanach Zjednoczonych.

Jednak w wielu stanach umożliwiono wyborcom nieobecnym w dniu wyborów odsyłanie głosu w sposób elektroniczny (internetowy). Wysyłanie kart wyborczych - przez e-mail lub fax - jest najczęściej zarezerwowane dla obywateli podlegających federalnej ustawie Uniformed and Overseas Citizens Absentee Vo-

30 D. Cavadini, L. Cimasoni, Case Studies on E-Voting, Seminar work on E-government, University of Fribourg, 2007, s. 10, http://diuf.unifr.ch/is/studentprojects/pdf/reports/eGov_HS07_Case_Studies_on_E-Voting_\%28DanieleCavadini_LorenzoCimasoni\%29.pdf [dostęp 14 października 2017 r.].

31 Swiss Post's e-voting solution. Electronic voting and elections for Switzerland, https:// www.post.ch/en/business/a-z-of-subjects/industry-solutions/swiss-post-e-voting [dostęp 11 października 2017 r.].

32 Swiss e-voting poised for expanded roll-out, 5 kwietnia 2017 r., https://www.swissinfo.ch/eng/politics/digital-democracy_swiss-e-voting-poised-for-expanded-roll-out/43087404 [dostęp 13 października 2017 r.]. 
ting Act (UOCAVA) ${ }^{33}$. Motywacją do wprowadzenia takiej możliwości były przede wszystkim trudności w terminowym otrzymywaniu i odsyłaniu kart wyborczych do komisji wyborczej (co szczególnie dotykało osoby przebywające za granicą).

W dwudziestu jeden stanach oraz dystrykcie Kolumbia możliwe więc jest odsyłanie kart wyborczych e-mailem lub faksem ${ }^{34}$. W sześciu stanach amerykańskich możliwe jest odsyłanie głosów faksem ${ }^{35}$. Tylko w pięciu stanach - Alabama, Alaska, Arizona, Dakota Północna i Missouri - możliwe jest głosowanie internetowe przez specjalny portal przeznaczony do głosowania.

W Missouri umożliwiono głosowanie wojskowym, którzy przebywają poza granicami państwa „w strefie wroga”, a w Alabamie głosowanie za pośrednictwem internetu możliwe jest wyłącznie dla wyborców podlegających pod ustawę UOCAVA i to tylko w formie pilotażowej. Dakota Północna i Arizona umożliwiają i-głosowanie wszystkim wyborcom UOCAVA, a na Alasce każdy wyborca może głosować za pośrednictwem portalu internetowego. W osiemnastu amerykańskich stanach nie ma możliwości przesyłania głosów elektronicznie ${ }^{36}$. Wyborcy mogą odesłać swoje karty do głosowania za pośrednictwem zwykłej poczty ${ }^{37}$.

Ostrożność i sceptycyzm wobec $i$-votingu jest związana $z$ faktem, że oddawanie głosu za pośrednictwem internetu (w przeciwieństwie do wysyłania kart do głosowania jako załącznika w poczcie elektronicznej) niesie za sobą duży poziom zagrożenia bezpieczeństwa. Zdaniem Alexa Haldermana, specjalisty w zakresie bezpieczeństwa komputerowego z Uniwersytetu Michigan: [t]echnologia nie jest przygotowana do bezpiecznego głosowania przez Internet ${ }^{38}$. Zaznaczyć należy, iż większość ekspertów, porównując odsyłanie głosów e-mailem lub faksem z i-głosowaniem, twierdzi, że głosy internetowe są masowo narażone na ataki hakerskie, podczas gdy odesłanie głosu pocztą elektroniczną lub faksem naraża tylko jeden głos (w załączniku). Pojawiają się też opinie, że $i$-voting jest bardziej skomplikowany niż bankowość online, do której często porównywane są portale do głosowania internetowego ${ }^{39}$.

33 Electronic Transmission of Ballots, 16 stycznia 2017 r., http://www.ncsl.org/research/ elections-and-campaigns/internet-voting.aspx [dostęp 10 października 2017 r.].

34 Colorado, Delaware, District of Columbia, Hawaii, Idaho, Indiana, Iowa, Kansas, Maine, Massachusetts, Mississippi, Montana, Nebraska, Nevada, New Jersey, New Mexico, North Carolina, Oregon, South Carolina, Utah, Washington i West Virginia.

35 California, Florida, Louisiana, Oklahoma, Rhode Island, Texas.

36 Arkansas, Connecticut, Georgia, Illinois, Kentucky, Maryland, Michigan, Minnesota, New Hampshire, New York, Ohio, Pennsylvania, South Dakota, Tennessee, Vermont, Virginia, Wisconsin i Wyoming.

37 Electronic Transmission, op. cit.

38 Internet Voting - Not Ready for Prime Time?, http://www.ncsl.org/research/elections-and-campaigns/the-canvass-february-2013.aspx\#Internet [dostęp 12 października 2017 r.].

39 Ibidem. 


\section{Norwegia}

Analizując doświadczenia europejskie związane z i-głosowaniem, wspomnieć można także o Norwegii, gdzie odbyły się dwie próby związane z $i$-votingem. Pierwsza z nich miała miejsce przy wyborach lokalnych w 2011 r. i obejmowała 10 gmin $^{40}$. Dwa lata później w wyborach parlamentarnych $i$-voting wykorzystano w 12 gminach. W obu przypadkach - w 2011 r. i w 2013 r. - i-głosowanie było dodatkowym sposobem głosowania względem tradycyjnego. W 2013 r. powyżej 250 tys. uprawnionych mogło skorzystać z głosowania za pomocą internetu. Głosowanie za pośrednictwem internetu możliwe było przedterminowo - w okresie od 12 sierpnia do 6 września. W dniu głosowania można było głosować wyłącznie w lokalu wyborczym. Głosowanie internetowe - szczególnie przez opozycję postrzegane było jako bardzo kontrowersyjne, przede wszystkim ze względów bezpieczeństwa. Po zwycięstwie przez te ugrupowania wyborów parlamentarnych w 2013 r., w czerwcu 2014 r. ogłoszono, że próby z i-głosowaniem zostały wstrzymane ${ }^{41}$.

Zgodnie z raportem dotyczącym i-głosowania w 2013 r. z możliwości i-votingu skorzystało około 70 tys. Norwegów, reprezentujących 38\% spośród 250 tys. uprawnionych. Z raportu wynikało również, że nie ma dowodów na to, że i-głosowanie wpływa na zwiększenie frekwencji wyborczej czy też mobilizuje nowe grupy wyborców (np. ludzi młodych) do głosowania ${ }^{42}$.

\section{Austria}

Próby głosowania za pośrednictwem internetu przeprowadzone były także w 2009 r. w Austrii w wyborach do Austriackiej Federacji Studentów (Hochschülerinnen und Hochschülerschaftswahlen). Pierwsza próba implementacji i-głosowania w Austrii okazała się technicznie skuteczna. Prawie 1\% (2161) uprawnionych studentów oddało swoje głosy drogą elektroniczną między 18 a 22 maja 2009 r. Do identyfikacji i uwierzytelnienia wykorzystano dowód osobisty (austriacki model inteligentnej karty z podpisem cyfrowym) oraz odpowiedni czytnik kart. Anonimowość została zagwarantowana przy użyciu protokołu kryptograficznego w fazie post-voting i była ona podobna do te samej procedury

40 S.B. Segaard, H. Baldersheim, J. Saglie, The Norwegian Trial with Internet Voting: Results and Challenges, Revista General de Derecho Público Comparado 2013, http://79.125.117.151/Publikasjoner/Bok-og-tidsskriftsartikler/2013/2013-031 [dostęp 14 października 2017 r.].

${ }_{41}$ J. Saglie, S.B. Segaard, Internet voting and the secret ballot in Norway: principles and popular understandings, „Journal of Elections, Public Opinion and Parties” 2016, t. 26, nr 2, s. 155-156.

42 E-voting experiments end in Norway amid security fears, 27 czerwca 2014 r., http:// www.bbc.com/news/technology-28055678 [dostęp 10 października 2017 r.]. 
przy głosowaniu korespondencyjnym ${ }^{43}$. Zaznaczyć trzeba, że głosowanie zostało unieważnione orzeczeniem austriackiego Trybunału Konstytucyjnego z 13 grudnia $2011 \mathrm{r}^{44}$.

\section{Głosowanie przez internet - argumenty zwolenników i przeciwników ${ }^{45}$}

Rozważania nad zagadnieniem wdrażania i-głosowania prowadzą do analizy motywów oraz potencjalnych korzyści i zagrożeń związanych z i-votingem ${ }^{46}$.

Najkorzystniejszą zmianą, jaką może przynieść $i$-voting, jest zwiększenie mobilności wyborców. Taki system głosowania umożliwia bowiem oddanie głosu w dowolnym miejscu i w dowolnym czasie (w granicach określonych prawem) nawet gdy wyborca pozostaje poza miejscem swojego zamieszkania. Ponadto dzięki nowym technologiom zwiększa się komfort oddawania głosów - wyborca już nie musi wychodzić $\mathrm{z}$ domu do lokalu wyborczego (lub na pocztę w przypadku głosowania korespondencyjnego), by tam oddać lub wysłać swój głos. Głosowanie internetowe przynosi także korzyści osobom niepełnosprawnym, które często mają trudności z dotarciem do lokali wyborczych.

Z punktu widzenia administracji głosowanie elektroniczne może przyspieszyć oraz zwiększyć dokładność przeliczania oddanych w wyborach czy referendach głosów. W tym kontekście zwraca się przede wszystkim uwagę na wyeliminowanie prawdopodobieństwa popełnienia błędu przez urzędników wyborczych oraz manipulacje w lokalach wyborczych. Ponadto wprowadzenie elektronicznego systemu rejestru wyborców mogłoby wyeliminować zdarzające się czasami przypadki wielokrotnego głosowania, a w państwach, gdzie jeszcze nie wprowadzono e-głosowania, elektroniczny centralny rejestr wyborców mógłby być zapewne pierwszym etapem na drodze do wprowadzenia $i$-voting $u^{47}$.

Systemy i-głosowania, gdzie funkcjonuje elektroniczny centralny rejestr wyborców, mogą przyczynić się do redukcji kosztów związanych z organizacją wy-

43 R. Krimmer, A. Ehringfeld, M.Traxl, The Use of E-Voting in the Austrian Federation of Students Elections 2009, s. 33, https://subs.emis.de/LNI/Proceedings/Proceedings167/33.pdf [dostęp 13 października 2017 r.].

44 E-Voting Pilot in Austria Cancelled by Constitutional Court, https://www.wu.ac.at/en/ evoting/news-details/detail/e-voting-pilot-in-austria-cancelled-by-constitutional-court/ [dostęp 15 października 2017 r.].

45 Szerzej zob. M. Musiał-Karg. Elektroniczne referendum w Szwajcarii, op. cit., s. 173176.

46 R. Krimmer, E-Voting in Austria. Current Status in and around Austria, 11 marca 2010 r., IECEG Conference, Belek, Turcja.

47 A. Rakowska, M. Rulka, Centralny elektroniczny rejestr wyborców podstawa reform prawa wyborczego, Instytut Spraw Publicznych, Warszawa 2011, s. 14. 


\section{Tabela 2. Mocne i słabe strony elektronicznego głosowania}

\begin{tabular}{|c|c|}
\hline Mocne strony elektronicznego głosowania & Słabe strony elektronicznego głosowania \\
\hline 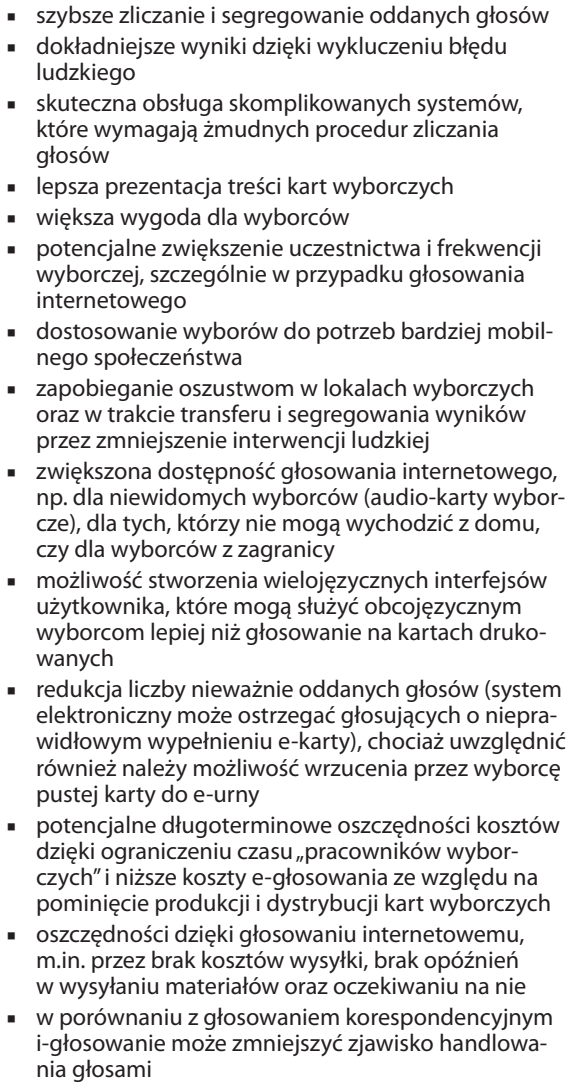 & $\begin{array}{l}\text { - } \text { brak przejrzystości } \\
\text { - } \text { ograniczona otwartość i zrozumienie systemu dla } \\
\text { - brak uzgodisodnionych standardów dla systemów e- } \\
\text { głosowania } \\
\text { - możliwość naruszenia tajności głosowania, zwłasz- } \\
\text { cza w systemach, w których odbywa się zarówno } \\
\text { uwierzytelnianie wyborców, jak i głosowanie } \\
\text { - ryzyko manipulacji przez tzw. insiderów (administra- } \\
\text { torów, obsługę systemów) z szerszym dostępem do } \\
\text { systemu lub przez hakerów z zewnątrz } \\
\text { - zwiększone koszty zarówno w przypadku zakupu, } \\
\text { jak i utrzymania systemu e-głosowania } \\
\text { - zwiększone wymogi bezpieczeństwa, jeśli chodzi } \\
\text { o ochronę systemu głosowania w czasie wyborów } \\
\text { i między wyborami, w tym podczas transportu, } \\
\text { - składowania i konserwacji } \\
\text { - zmniejszony poziom kontroli przez administrację } \\
\text { wyborczą } \\
\text { - możliwości ponownego liczenia głosów } \\
\text { - potrzebne dodatkowe kampanie edukujące wybor- } \\
\text { - ców } \\
\text { - możliwy konflikt z istniejącymi przepisami prawnymi } \\
\text { - możliwy brak zaufania wyborców wobec wyborów } \\
\text { elektronicznych, co jest skutkiem wskazanych wyżej } \\
\text { słabych stron }\end{array}$ \\
\hline
\end{tabular}

Źródło: Introducing Electronic Voting: Essential Considerations, International Institute for Democracy and Electoral Assistance, Policy Paper, December 2011, s. 8-9.

borów czy referendów. Argument ten jest uzasadniany tym, że przy okazji i-głosowania nie ma potrzeby angażowania do pracy w lokalach wyborczych dużej liczby urzędników wyborczych, którzy są niezbędni, gdy wybory organizowane są tradycyjnie (przy urnach wyborczych).

Wprowadzenie internetu do wyborów wywołuje dyskusję na temat słabych stron i-głosowania. Potwierdzeniem tego jest m.in. fakt, że wiele państw wyraziło zaniepokojenie, iż głosowanie elektroniczne może doprowadzić do masowych oszustw wyborczych.

Innym ważnym problemem jest identyfikacja wyborców. Z jednej strony należy przyznać, że hasło i podpis elektroniczny są pomocne na etapie głosowania, ale $\mathrm{z}$ drugiej strony trzeba brać także pod uwagę, że dane te mogą być wykorzystane nie przez wyborcę, ale przez osoby trzecie. 
Systemy głosowania za pomocą internetu narażone są ponadto na wiele problemów technicznych. Mogą być bowiem przedmiotem ataków, które z kolei mogą doprowadzić do istotnych zakłóceń procesu głosowania. Dlatego też serwery, systemy, komputery czy kioski do głosowania powinny być tak zabezpieczone, aby nie mogły być naruszone lub zainfekowane wirusami.

Analizując literaturę poświęconą elektronicznemu głosowaniu, można wskazać najczęściej pojawiające się mocne i słabe strony i-votingu. Większość ze wskazywanych cech została ujęta w tabeli 2, która stanowi podsumowanie jednej z części raportu szwedzkiego International Institute for Democracy and Electoral Assistance pt. Introducing Electronic Voting: Essential Considerations.

\section{Koszty głosowania internetowego, wybrane przykłady}

Jeśli chodzi o koszty związane z wdrożeniem $i$-votingu, to trzeba zauważyć, że opracowanie, przygotowanie i samo wdrożenie systemu i-głosowania w krótkiej perspektywie czasu wiąże się z wysokimi kosztami, które - jak argumentują zwolennicy e-głosowania - będą znacznie mniejsze w długim okresie.

Austria (Internet voting, wybory do rady studenckiej)

- 3,8 euro na zarejestrowanego (403 euro/wyborcę),

- 870 tys. euro na 230 tys. zarejestrowanych, 2161 wyborców ${ }^{48}$.

\section{Estonia (Internet voting)}

- 1-5 euro na wyborcę lub 0,1-0,5 euro na zarejestrowanego,

- 500 tys. euro ustanowienie systemu (bez systemu uwierzytelniania); koszty bieżące 100 tys. euro na 100 tys. wyborców lub $1 \mathrm{mln}$ zarejestrowanych.

Szwajcaria (Internet voting)

- 0,3 euro/wyborcę (zakładając trzy elekcje rocznie),

- utrzymanie: $10 \mathrm{mln}$ euro w okresie 10 lat dla $1 \mathrm{mln}$ wyborców.

Powyższe zestawienie ${ }^{49}$ opracowane przez International Institute for Democracy and Electoral Assistance przedstawia szacunki i koszty wdrożenia głosowania za pomocą internetu. Nadmienić należy, że koszty wdrożenia systemu i-votingu zależne są od zastosowanych technologii, a także uwarunkowań implementacji takich rozwiązań (liczba wyborców, liczba wyborów).

48 BM für Wissenschaft und Forschung. Anfragebeantwortung, http://www.parlament. gv.at/PAKT/VHG/XXIV/AB/AB_02562/fnameorig_166607 [dostęp 13 października 2017 r.].

49 Introducing Electronic Voting: Essential Considerations, International Institute for Democracy and Electoral Assistance, Policy Paper, December 2011, s. 31-32. 


\section{Wnioski}

Prowadzone w niniejszym artykule rozważania skłaniają do sformułowania kilku wniosków, które przedstawiono poniżej.

- Głosowanie za pośrednictwem internetu staje się coraz bardziej dyskutowanym/rozważanym sposobem głosowania w wyborach i referendach. Dowodem tego jest fakt, że w ostatnich latach w wielu państwach toczy się dyskusja na temat wdrożenia i-głosowania, a także przeprowadzane są/były głosowania testowe i pilotażowe, by sprawdzić funkcjonalność $i$-votingu.

- Państwem, któremu udało się z sukcesem wdrożyć głosowanie internetowe, jest Estonia, gdzie od 2005 r. można głosować za pośrednictwem internetu w wyborach lokalnych, parlamentarnych oraz w wyborach do Parlamentu Europejskiego. Estonia jest jedynym państwem na świecie, gdzie i-głosowanie dostępne jest dla każdej osoby uprawnionej do głosowania. Drugim państwem, w których głosowanie internetowe zostało już mocno rozwinięte i przetestowane, jest Szwajcaria. Po problemach z zabezpieczeniem głosowania za pośrednictwem Zurych E-voting System, postanowiono zawiesić dalsze testy tego systemu, a przedsięwzięcie przekazano Swiss Post. Obecnie systemy $i$-votingu w Szwajcarii wdrażane są przy wykorzystaniu systemu kantonu Genewa oraz Swiss Post. Mimo prób wdrożenia i-głosowania w wielu innych państwach (USA, Norwegia, Austria) system Remote Internet Voting nie działa w takim zakresie jak w Estonii.

- Procedury oddawania głosów za pośrednictwem i-votingu są zróżnicowane. Większość z systemów podobna jest do bankowości elektronicznej. Głosy oddaje się na specjalnie przygotowanych portalach internetowych. W Estonii niezbędne jest wykorzystanie eID-card lub Mobile-ID do oddania głosu za pośrednictwem internetu. W szwajcarskim systemie kantonu Genewa niezbędne jest posiadanie karty do głosowania, na której umieszczone są odpowiednie kody, umożliwiające uwierzytelnienie wyborcy.

- Za wcześnie jest, by formułować wnioski dotyczące wpływu wykorzystania i-votingu na frekwencję wyborczą. Widoczny jest pewien umiarkowany wpływ na partycypację w wyborach lokalnych i w minimalny sposób w wyborach parlamentarnych w Estonii, jednak trudno jest jednoznacznie to stwierdzić. Istnieje potrzeba, by wraz ze wzrostem liczby elekcji z wykorzystaniem i-głosowania pogłębiać badania nad wpływem $i$-votingu na frekwencję. Dodać należy, że w Szwajcarii, gdzie przeprowadzono wiele prób i-votingu, nie odnotowano praktycznie żadnej zmiany, jeśli chodzi o frekwencję.

- Najważniejsze ryzyko związane z wykorzystaniem $i$-votingu w elekcjach jest natury technicznej. Najczęściej wysuwanym argumentem przeciwników głosowania internetowego jest narażenie systemów $i$-votingu na ataki hakerskie. Oprócz tego pojawiają się zarzuty zmniejszonego poziomu kontroli nad i-wyborami przez administrację wyborczą, co wynika z tego, że głosowanie odby- 
wa się w tzw. niekontrolowanym środowisku. Głównym atutem i-głosowania pojawiającym się w dyskusjach jest zwiększenie wygody wyborców, którzy $\mathrm{z}$ dowolnego miejsca i w dowolnym czasie wyznaczonym przez komisję wyborczą mogą oddać głos z komputera osobistego podłączonego do internetu. Ma to szczególne znaczenie dla osób niepełnosprawnych ruchowo lub dla tych, którzy w dniu głosowania przebywają za granicą.

- Analiza kosztów wdrożenia głosowania internetowego pozwala sformułować wniosek, że są one zróżnicowane - w zależności od państwa, systemu, liczby wyborców. Specjaliści od wdrażania systemów i-głosowania argumentują jednak, że mimo wysokich kosztów na początku wdrażania systemu, w dłuższym okresie są one zdecydowanie niższe (brak potrzeby drukowania kart wyborczych, angażowania administracji wyborczej, zmniejsza się liczba lokali wyborczych itp.).

\section{Bibliografia}

Braendli D., The scope of e-voting in Switzerland, E-Voting and Electronic Democracy: Present and the Future - An International Conference, Seoul, South Korea, March 17-18 2005.

Cavadini D., Cimasoni L., Case Studies on E-Voting, Seminar work on E-government, University of Fribourg, 2007, http://diuf.unifr.ch/is/studentprojects/pdf/reports/ eGov_HS07_Case_Studies_on_E-Voting_\%28DanieleCavadini_LorenzoCimasoni\%29.pdf.

Kaczmarczyk A., Czajkowski R., E-Głosowanie - niezbędny element elektronicznej platformy do obstugi procedur $w$ demokracji $w$ społeczeństwie informacyjnym. E-vote an essential element of electronic platform for services for democratic procedures in the Information Society, referat prezentowany na konferencji „Tworzenie mechanizmów i struktur rozwoju elektronicznej gospodarki w Polsce", Warszawa, 12 czerwca 2001 r., http://www.logistyka.net.pl/images/articles/1375/Ref-Czajkowski.doc.

Krimmer R., Ehringfeld A., Traxl M., The Use of E-Voting in the Austrian Federation of Students Elections 2009, https://subs.emis.de/LNI/Proceedings/Proceedings167/33. pdf.

Krimmer R., E-voting as a New Form of Voting, [w:] Explorations in eGovernment \& eGovernance. Volume 2: Selected proceedings of the Second International Conference on eGovernment and eGovernance, red. A. Balci, C. Can Actan, O. Dalbay, Antalya 2010.

Krimmer R., E-Voting in Austria. Current Status in and around Austria, 11 marca 2010 r., IECEG Conference, Belek, Turcja.

Maaten E., Towards remote e-voting: Estonian case, Elections Departament. Chancellery of the Riigikogu (Parliament), Tallin 2004.

Musiał-Karg M., Elektroniczne referendum w Szwajcarii. Wybrane kierunki zmian helweckiej demokracji bezpośredniej, Poznań 2012. 
Musiał-Karg M., E-voting (as a form of E-democracy) in the European Countries [w:] Explorations in eGovernment \& eGovernance. Volume 2: Selected proceedings of the Second International Conference on eGovernment and eGovernance, red. A. Balci, C. Can Actan, O. Dalbay, Antalya 2010.

Musiał-Karg M., Internetowe głosowanie w Estonii na przykładzie wyborów w latach 20052009, „Przegląd Politologiczny” 2011, nr 3.

Nowina-Konopka M., Elektroniczna urna, http://www.rpo.gov.pl/pliki/12066058070.pdf.

Rakowska A., Rulka M., Centralny elektroniczny rejestr wyborców podstawa reform prawa wyborczego, Instytut Spraw Publicznych, Warszawa 2011.

Saglie J., Segaard S. B., Internet voting and the secret ballot in Norway: principles and popular understandings, „Journal of Elections, Public Opinion and Parties” 2016, t. 26, nr 2, https://doi.org/10.1080/17457289.2016.1145687.

Segaard S. B., Baldersheim H., Saglie J., The Norwegian Trial with Internet Voting: Results and Challenges, Revista General de Derecho Público Comparado 2013, http://79.125.117.151/Publikasjoner/Bok-og-tidsskriftsartikler/2013/2013-031.

Serdült U., The Swiss Experience with Internet Voting, The Centre for E-Democracy, 2016, http://www.centreforedemocracy.com/wp-content/uploads/2016/10/Policy_Brief_ Uwe_Serduit.pdf.

Solvak M., Vassil K., E-voting in Estonia: Technological Diffusion and Other Developments Over Ten Years (2005-2015), University of Tartu \& Estonian National Electoral Committee, Tartu 2016.

Vinkel P., Internet Voting in Estonia, http://www.eis.fi/tapahtumat/2008/Seminaari200809/Finnish_delegation_Internet_voting.pdf.

Weber A., Taglioni G., Swiss Elections to the National Council: First trials with e-voting in elections at federal level, Dagstuhl-Seminar 11281: Verifiable Elections and the Public (10.-15.07.2011), http://arxiv.org/ftp/arxiv/papers/1109/1109.2489.pdf. 